Gut, 1982, 23, 675-682

\title{
Effects of fundic vagotomy and cholinergic replacement on pentagastrin dose responsive gastric acid and pepsin secretion in man*
}

\author{
B I HIRSCHOWITZ $†$ and C A HELMAN \\ From the Division of Gastroenterology, University of Alabama, Birmingham, and Veterans Administration \\ Medical Center, Birmingham, Alabama, USA
}

SUMmARY The effects of fundic vagotomy on acid and pepsin secretion in 12 patients (10 males, two females; nine duodenal ulcer, three gastric ulcer) were studied using a pentagastrin dose response before and after vagotomy. In the intact state $\mathrm{H}, \mathrm{Cl}$, and pepsin output all had the same $\mathrm{ED}_{50}, 120-127 \mathrm{pmol} / \mathrm{kg} / \mathrm{h}$. Vagotomy reduced basal output of acid by $78 \%, \mathrm{Cl}^{-}$by $50 \%$, and pepsin by $62 \%$. Postvagotomy basal outputs were not related to preoperative levels, while maximum acid output was reduced by an average of $35 \%$, proportionally to the preoperative output $(r=0.94)$. Vagotomy uncompetitively $\left(\mathrm{ED}_{50}\right.$ increase, Vmax decrease) inhibited the pentagastrin dose response of acid, chloride, and pepsin output. Postoperatively, a six-fold greater dose of pentagastrin (450 vs $76 \mathrm{pmol} / \mathrm{kg} / \mathrm{h}$ ) was required to stimulate acid to $50 \%$ of its preoperative maximum output. For pepsin secretion the increase was 12-fold (185 vs 15 $\mathrm{pmol} / \mathrm{kg} / \mathrm{h}$ ). In five of the nine duodenal ulcer patients pentagastrin dose responses were repeated with a background infusion of urecholine, $20 \mu \mathrm{g} / \mathrm{kg} / \mathrm{h}$. Urecholine increased basal and peak acid, pepsin, and chloride outputs, and the ratio of basal:maximal almost to prevagotomy levels; it also restored the sensitivity to pentagastrin. Serum gastrin was not significantly changed by urecholine or by vagotomy. We conclude that the level of basal acid and pepsin secretion in ulcer patients, which is largely eliminated by vagotomy, is dependent on the vagus and not on serum gastrin. The effects of vagotomy are functional, are due to cholinergic withdrawal, and usually can be restored by cholinergic replacement.

Fundic (highly selective) vagotomy is an established and important treatment for duodenal ulcer. The effect of vagotomy on acid secretion has been extensively investigated in man and animals, but there are only scanty data on pepsin secretion. ${ }^{1-4}$ Other than secretion studies to test the completeness of vagotomy, based on glucoprivation, ${ }^{5}$ studies of the effects of vagotomy on acid secretion have dealt largely with single maximum dose histamine- ${ }^{4}$ or pentagastrin- ${ }^{367}$ stimulated acid secretion. Even though dose responses are a powerful tool in the

\footnotetext{
* Published in Abstract form in Gastroenterology 80, 1175, 1981. + Address for correspondence: Basil I Hirschowitz, Division of Gastroenterology, University of Alabama in Birmingham, Birmingham, Alabama 35294 USA.

Received for publication 26 November 1981
}

study of gastric secretion, they have rarely been used to study the effects of vagotomy in man.

In man a cholinergic background generally restores to prevagotomy levels the maximum acid response to histamine. ${ }^{6}$ Roland $e t a l^{319}$ however, could not confirm this for pentagastrin. The cholinergic agents apparently do not increase the maximum levels attainable with pentagastrin or histamine intact in man, ${ }^{8-10}$ as they do in the dog. ${ }^{12}$

We used the pentagastrin dose response before and after surgery to analyse the effects of fundic vagotomy on basal and stimulated acid and pepsin secretion, and on the kinetics of response to pentagastrin. We sought to determine whether the effects of vagotomy could be reversed by a cholinergic background. From this information we hoped better to understand the role of the vagus in gastric secretion in ulcer disease. 


\section{Methods}

The study was approved by the Institutional Review Board for Human Experimentation and all the patients agreed to the studies after being informed of their purpose and methods.

Ten men and two women, aged 19 to 53 years (mean 37 years, $\mathrm{SE} \pm 3.6$ ), nine with duodenal and three with gastric ulcer had pentagastrin doseresponse gastric secretion studies before and one to nine (mean $3 \pm 0 \cdot 8$ ) months after fundic vagotomy (highly selective vagotomy). They weighed 66.7 $\mathrm{kg} \pm 4$ before and $66 \cdot 3 \mathrm{~kg} \pm 3 \cdot 8$ after vagotomy.

In five of the nine duodenal ulcer subjects after vagotomy pentagastrin dose-response studies were also performed with a background of urecholine (bethanechol) $20 \mu \mathrm{g} / \mathrm{kg} / \mathrm{h}$. Three of these patients were studied again three to four years after vagotomy with new pentagastrin control studies, so that the paired studies in this group (pentagastrin dose-response \pm urecholine) were performed within a week of each other. A small but not significant increase in acid and pepsin outputs occurred during the interval between the two postoperative studies.

Each study was carried out in the fasting state, more than 10 hours after the evening meal. All antisecretory drugs were withdrawn at least 36 hours before study. A Salem sump nasogastric tube was positioned fluoroscopically or by the method of Hassan and Hobsley, ${ }^{18}$ and connected to moderate suction supplemented by syringe suction at intervals. Saliva was aspirated continuously by a dental suction device. After the fasting residue was removed and measured, timed consecutive 10 minute samples were collected. After $\mathbf{4 0}$ minutes in the basal state, pentagastrin (Peptavlon, Ayerst, M.W. 767) was given from a Harvard syringe pump in doses of $0.1,0.25,1.0$, and $2.5 \mu \mathrm{g} / \mathrm{kg} / \mathrm{h}$ in successive 40 minute periods. Acid was titrated to $\mathrm{pH} 7.0$ with $0.04 \mathrm{~N} \mathrm{NaOH}$; chloride was measured by a Corning coulometric chloridimeter and pepsin by an automated protein digestion method ${ }^{11}$ using haemoglobin substrate in which $1 \mu \mathrm{g}$ crystallised pepsinogen (Sigma Chemical Co, St Louis, MO) has the activity of four peptic units: 1000 peptic units equal 1 peptic kilo unit.

\section{STATISTICAL ANALYSIS}

To allow for equilibration, output for each dose step was calculated from the last three 10 minute samples in each 40 minute period. Data for individual subjects were compared by paired $t$ test; linear correlations were performed for groups of paired data. A value of $p<0.05$ was considered significant.

Dose responses were analysed by an exponential model $\mathrm{V}=\mathrm{Vmax}-\mathrm{be}^{-\mathrm{cS}},{ }^{*}$ incorporating statistical analyses, so that the significance of the fit and the derived data, threshold (T), $\mathrm{Km}, \mathrm{ED}_{50}$, and Vmax could be determined. ${ }^{12}$ Where output is present before a stimulus is applied - for example, basal secretion in man - the exponential model provides the best analyses of the dose response. Here the basal secretion can be described as that which would result from the equivalent of a calculated dose $(T)$ of the drug subsequently given in graded doses. This is analagous to determining the concentration of a constituent in solution by measuring the change resulting from the addition of known increments of the same constituents and extrapolating back to 0 .

\section{Results}

\section{FUNDIC VAGOTOMY}

\section{Dose response}

Vagotomy reduced mean basal acid output by $78 \%$, chloride by $50 \%$, and pepsin by $62 \%$ (Table 1 ). Stimulated acid, chloride, and pepsin output curves were displaced downwards parallel to the prevagotomy curves, with reduction of the maximum outputs by about $35 \%$ (Figs 1,2). With Vmax decreased, $\mathrm{ED}_{50}$ almost doubled for $\mathrm{H}^{+}$and $\mathrm{C1}^{-}$ and increased by $50 \%$ for pepsin - that is, vagotomy produced an uncompetitive inhibition ${ }^{12}$ of the pentagastrin dose-response. With the reduction of ratios of basal:maximum output, $T$, as a fraction of $\mathrm{ED}_{50}$, was proportionately decreased (Table 1).

Taking into consideration the reduction in maximum outputs, the effect of vagotomy on secretion was even more profound when we calculated the amount of pentagastrin required to stimulate the stomach to secrete $50 \%$ of the maximum prevagotomy output of acid $(19 \mathrm{mmol} / \mathrm{h})$ and pepsin (300 KU) (Fig 1). For acid the increase was six-fold (450 vs $76 \mathrm{pmol} / \mathrm{kg} / \mathrm{h})$ and for pepsin 12-fold (185 vs $15 \mathrm{pmol} / \mathrm{kg} / \mathrm{h}$ ).

\section{Basal and maximal outputs}

The effects of vagotomy were also examined in the conventional way by comparing basal and maximal outputs in individual patients. Basal outputs, especially the larger outputs, were markedly reduced in 10 of the 12 patients. Postvagotomy values were not related to preoperative levels ( $r=0.09$ and -0.06 respectively for acid and pepsin) (Fig 2). Individual basal acid and pepsin outputs as a percentage of maximum outputs were lower after

\footnotetext{
* $\mathrm{V}=$ output of $\mathrm{H}^{+}$, pepsin, etc; $\mathrm{S}=$ dose of stimulant; $\mathrm{T}=$ calculated threshold $=\mathrm{c} / \mathrm{b} ; \mathrm{Km}=$ dose of exogenous stimulant required to stimulate output to $50 \%$ of calculated maximum (Vmax); $c$ and b are calculated constants. $\mathrm{ED}_{50}$ is the total dose which would be required to stimulate output to $50 \%$ of maximum, if there were no basal output. $\mathrm{Km}-\mathrm{T}=E D_{\mathbf{5}}$.
} 
Table 1 Effect of fundic vagotomy in 12 patients on basal and maximal acid, chloride, and pepsin outputs

\begin{tabular}{|c|c|c|c|c|c|c|}
\hline & \multicolumn{2}{|l|}{ Acid (mmol/h) } & \multicolumn{2}{|c|}{ Chloride ( $\mathrm{mmol} / \mathrm{h})$} & \multicolumn{2}{|c|}{ Pepsin $(P K U / h)$} \\
\hline & Prevagotomy & Postvagotomy & Prevagotomy & Postvagotomy & Prevagotomy & Postvagotomy \\
\hline BAO & $8 \cdot 8 \pm 2 \cdot 4^{*}$ & $1.95 \pm 0.72 \dagger$ & $16 \cdot 4 \pm 3 \cdot 2$ & $8 \cdot 4 \pm 1 \cdot 7 \dagger$ & $280 \pm 58$ & $108 \pm 29 \ddagger$ \\
\hline PAO & $37 \cdot 8 \pm 6 \cdot 1^{*}$ & $24.8 \pm 4 \cdot 4 \dagger$ & $49 \cdot 6 \pm 7 \cdot 3$ & $33 \cdot 2 \pm 4 \cdot 6 \dagger$ & $618 \pm 116$ & $475 \pm 66 \ddagger$ \\
\hline BAO:PAO \% & 23 & 8 & 33 & 25 & 45 & 23 \\
\hline$T \S$ & $-51 \pm 4 \cdot 4$ & $-35 \pm 4 \cdot 2$ & $-78 \pm 3 \cdot 7$ & $-109 \pm 8 \cdot 9 \ddagger$ & $-105 \pm 9 \cdot 6$ & $-71 \pm 7 \cdot 6 \ddagger$ \\
\hline $\mathrm{Km} \S$ & $76 \pm 4 \cdot 9$ & $202 \pm 20 \dagger$ & $45 \pm 2 \cdot 5$ & $127 \pm 9 \cdot 2+$ & $15 \pm 1 \cdot 3$ & $107 \pm 8 \cdot 1 \dagger$ \\
\hline $\mathrm{ED}_{50} \S$ & 127 & 237 & 123 & 236 & 120 & 178 \\
\hline $\mathrm{T} / \mathrm{ED}_{50} \%$ & 40 & 15 & 63 & 46 & 88 & 40 \\
\hline
\end{tabular}

From the pentagastrin dose response we have calculated the kinetic parameters $\mathrm{T}$ (threshold) and $\mathrm{Km}(\mathrm{pmol} / \mathrm{kg} / \mathrm{h}) . \mathrm{ED} 50=(\mathrm{Km}-\mathrm{T})$. Kinetic analysis was by the exponential model $\mathrm{V}=\mathrm{Vmax}-\mathrm{be}^{-\mathrm{cs}}$. Correlation $(r)$ between observed and calculated outputs $(\mathrm{n}=5)$, was 0.99 or better in each case.

* SEM. $\quad+\mathrm{p}<0.01$. $\ddagger \mathrm{p}<0.05$. § Pentagastrin dose $\mathrm{pmol} / \mathrm{kg} / \mathrm{h}$.

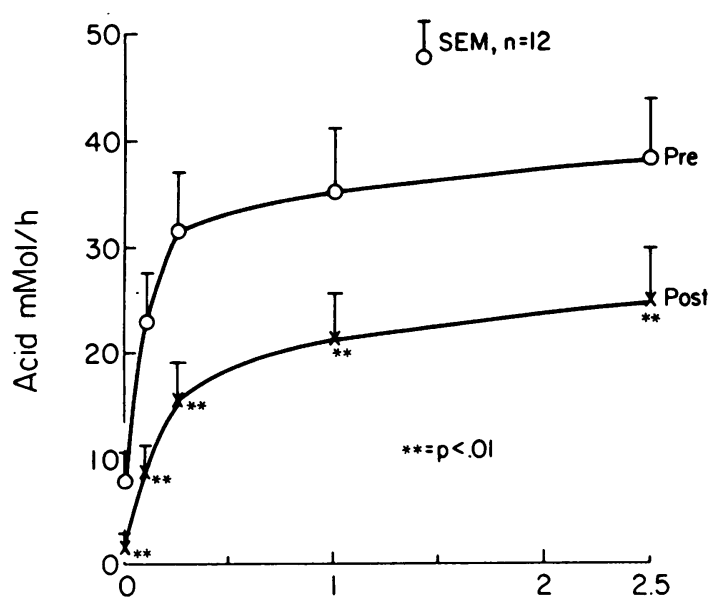

vagotomy - acid $6.3 \% \pm 1.09$ vs $16.8 \% \pm 2 \cdot 7, \mathrm{p}<0.05$ and pepsin $23.3 \% \pm 3.7$ vs $39.7 \% \pm 6.1, \mathrm{p}<0.05$. There was good positive correlation between maximum acid $(r=0.942)$ and pepsin $(r=0.619)$ outputs in the pre- and postoperative states (Fig 3). Thus vagotomy produced a proportional decrease in maximum output but a quite disproportional absolute reduction in basal outputs.

CHOLINERGIC REPLACEMENT

Five of the nine duodenal ulcer patients were also studied postvagotomy with pentagastrin dose

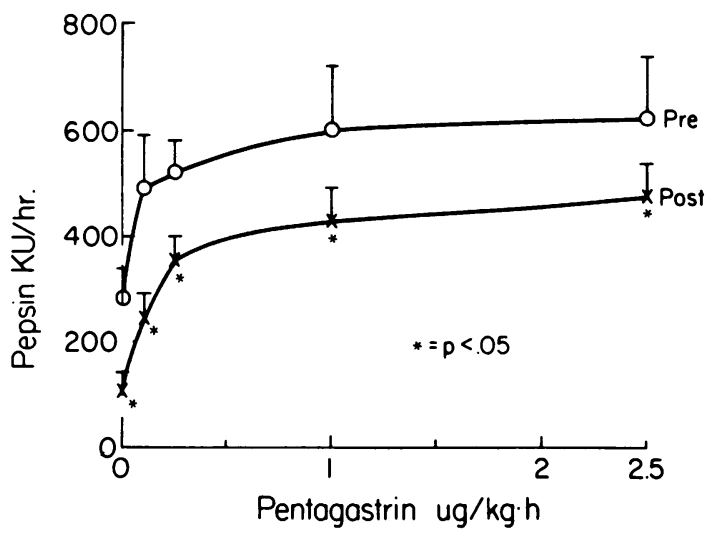

Fig. 1 Mean $\pm S E M$ basal and stimulated acid (top) and pepsin (bottom) output curves in 12 patients given graded doses of pentagastrin before and after fundic vagotomy. * differences by paired t test.

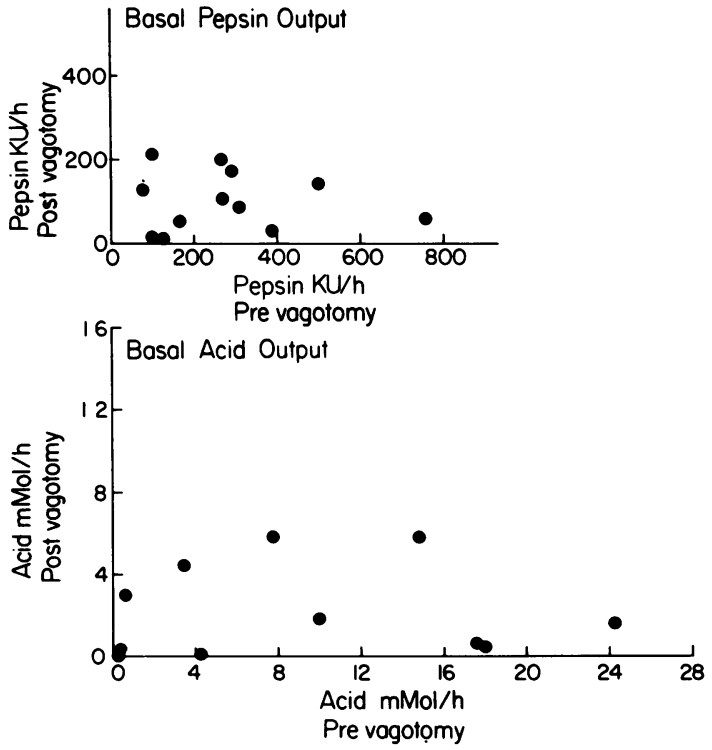

Fig. 2 Basal acid and pepsin outputs pre-and postvagotomy $(n=12)$. Correlation coefficients are not significantly different from 0. 
Fig. 3 Maximum acid and pepsin outputs in 12 patients pre- and post-vagotomy. For acid $y=747 x-4.9, r=0.942$; for pepsin $y=0.43 x+190, r=0.62$.
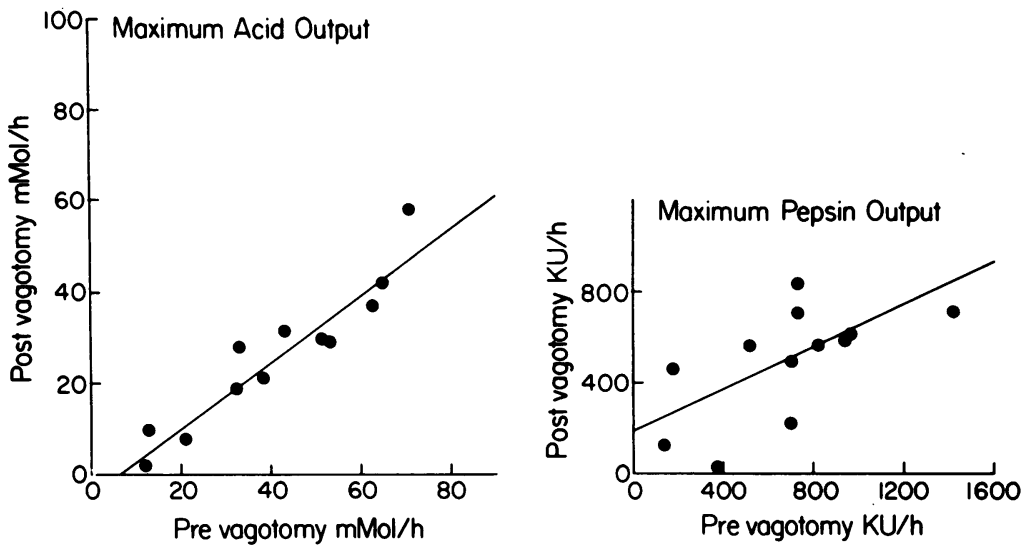

responses without and with a background of urecholine $20 \mu \mathrm{g} / \mathrm{kg} / \mathrm{h}$. Urecholine significantly increased basal and peak pentagastrin-stimulated acid and pepsin outputs (Figs 4, 5).

\section{Dose responses}

Urecholine reversed the effects of vagotomy, producing a parallel upward displacement of the pentagastrin dose response of both acid and pepsin outputs to levels not significantly different from prevagotomy (Fig 6). Urecholine also restored $\mathrm{T}$, $\mathrm{Km}$, and $\mathrm{ED}_{50}$ to or below preoperative levels (Table 2), and produced these effects by raising basal secretion, thus increasing $\mathrm{T}$ and reducing $\mathrm{Km}-$ that is, increasing the sensitivity to pentagastrin.
Basal and peak outputs

Basal acid output, peak acid output, and the ratio of basal acid output:peak acid output that were significantly depressed by vagotomy $(p<0.05)$ were restored to between 84 and $93 \%$ of preoperative levels. Similar urecholine effects were seen on chloride and pepsin secretion, with restoration to $92-100 \%$ of prevagotomy basal and peak outputs (Table 2).

\section{SERUM GASTRIN}

Mean fasting serum gastrin was $130 \pm 35 \mathrm{pg} / \mathrm{ml}$ before and $158 \pm 41$ after vagotomy. The difference is not significant. Fasting serum gastrin in five patients given urecholine was $120 \pm 37 \mathrm{pg} / \mathrm{ml}$; after
Fig. 4 Individual basal and peak acid output using pentagastrin dose response in five duodenal ulcer patients before fundic vagotomy, one to nine months later

(postvagotomy no. 1), three to four years later (no. 2), and within one week of the latter with background urecholine 20 $\mu \mathrm{g} / \mathrm{kg} / \mathrm{h}$. Mean values are shown by the thick dashed line.
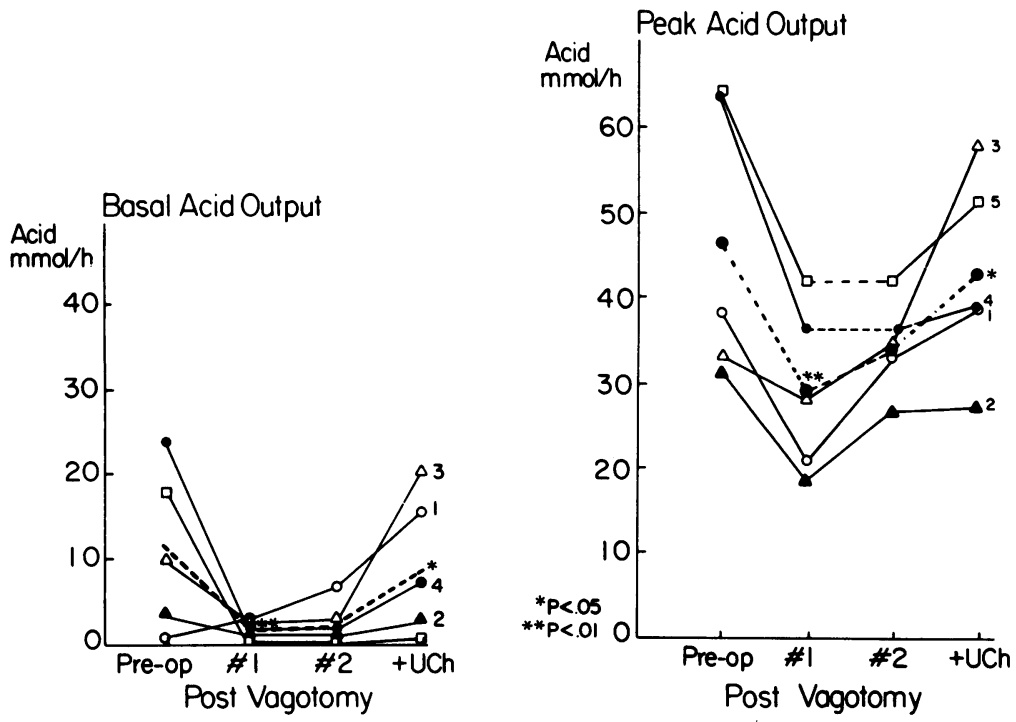
Fig. 5 Individual basal and peak pepsin outputs as in Fig. 4.
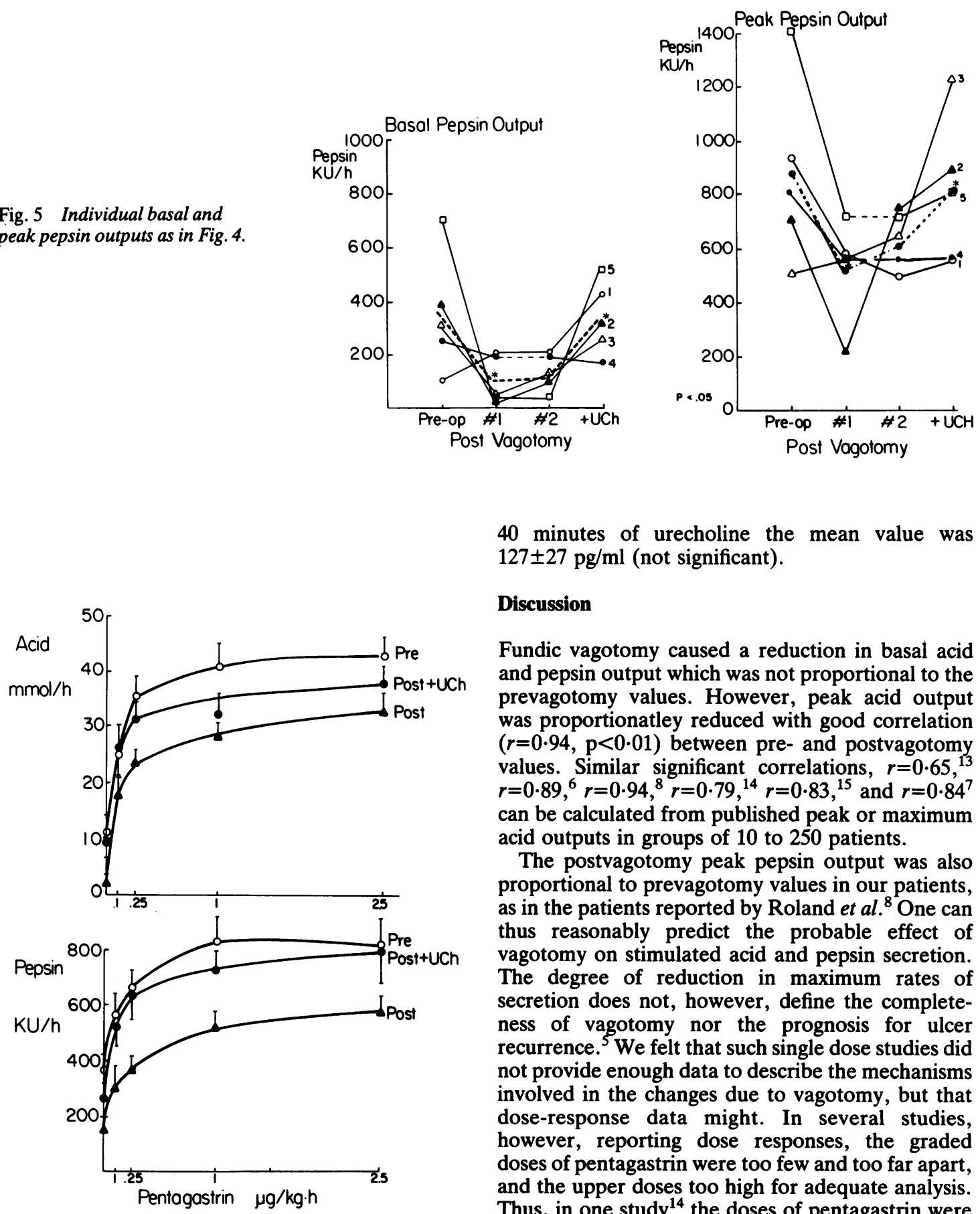

40 minutes of urecholine the mean value was $127 \pm 27 \mathrm{pg} / \mathrm{ml}$ (not significant).

\section{Discussion}

Fundic vagotomy caused a reduction in basal acid and pepsin output which was not proportional to the prevagotomy values. However, peak acid output was proportionatley reduced with good correlation $(r=0.94, \mathrm{p}<0.01)$ between pre- and postvagotomy values. Similar significant correlations, $r=0.65,{ }^{13}$ $r=0.89,{ }^{6} r=0.94,{ }^{8} r=0.79,{ }^{14} r=0.83,{ }^{15}$ and $r=0.84^{7}$ can be calculated from published peak or maximum acid outputs in groups of 10 to 250 patients.

The postvagotomy peak pepsin output was also proportional to prevagotomy values in our patients, as in the patients reported by Roland et al. ${ }^{8}$ One can thus reasonably predict the probable effect of vagotomy on stimulated acid and pepsin secretion. The degree of reduction in maximum rates of secretion does not, however, define the completeness of vagotomy nor the prognosis for ulcer recurrence. ${ }^{5}$ We felt that such single dose studies did not provide enough data to describe the mechanisms involved in the changes due to vagotomy, but that dose-response data might. In several studies, however, reporting dose responses, the graded doses of pentagastrin were too few and too far apart, and the upper doses too high for adequate analysis. Thus, in one study ${ }^{14}$ the doses of pentagastrin were $0.5,2$, and $8 \mu \mathrm{g} / \mathrm{kg} / \mathrm{h}$ and in another ${ }^{8} 0 \cdot 15,1.5$, and $15 \mu \mathrm{g} / \mathrm{kg} / \mathrm{h}$. As the $\mathrm{ED}_{50}$ or $\mathrm{Km}$ for acid is about $0 \cdot 1$

Fig. 6 Dose responsive acid and pepsin output in five duodenal ulcer patients before and after fundic vagotomy. The latter experiments were repeated with a background infusion of urecholine $20 \mathrm{\mu g} / \mathrm{kg} / \mathrm{h}$. 
Table 2 Basal and peak outputs of acid, chloride, and pepsin in five duodenal ulcer patients studied with pentagastrin dose response before and after fundic vagotomy

\begin{tabular}{|c|c|c|c|c|c|c|c|}
\hline & Basal & Peak & $\begin{array}{c}\text { Basal:peak }+ \\
\text { (\%) }\end{array}$ & $T^{*}$ & $K m^{*}$ & $E D_{50^{*}}$ & $T: E D_{50}$ \\
\hline $\begin{array}{l}\text { Acid (mmol/h) } \\
\text { Prevagotomy } \\
\text { Postvagotomy } \\
\text { + urecholine } \\
\% \text { of prevagotomy }\end{array}$ & $\begin{array}{l}11 \cdot 4 \pm 4 \cdot 2 \\
2 \cdot 4 \pm 1 \cdot 2 \\
9 \cdot 6 \pm 3 \cdot 8 \\
84 \%\end{array}$ & $\begin{array}{l}46 \cdot 2 \pm 7 \cdot 4 \\
34 \cdot 6 \pm 2 \cdot 4 \\
43 \pm 5 \cdot 4 \\
93 \%\end{array}$ & $\begin{array}{l}24 \pm 6 \cdot 5 \\
7 \pm 3 \cdot 9 \\
22 \pm 7 \cdot 5 \\
91 \%\end{array}$ & $\begin{array}{l}-68 \pm 4 \cdot 1 \\
-22 \pm 12 \\
-51 \pm 3 \cdot 8\end{array}$ & $\begin{array}{l}83 \pm 4 \cdot 3 \\
141 \pm 20 \\
64 \pm 1 \cdot 8\end{array}$ & $\begin{array}{l}151 \\
163 \\
115\end{array}$ & $\begin{array}{l}45 \% \\
13 \% \\
44 \%\end{array}$ \\
\hline $\begin{array}{l}\text { Pepsin (PKU/h) } \\
\text { Prevagotomy } \\
\text { Postvagotomy } \\
\text { + urecholine } \\
\% \text { of prevagotomy }\end{array}$ & $\begin{array}{l}360 \pm 108 \\
75 \pm 28 \\
334 \pm 26 \\
92 \%\end{array}$ & $\begin{array}{l}882 \pm 152 \\
634 \pm 46 \\
816 \pm 124 \\
93 \%\end{array}$ & $\begin{array}{l}42 \pm 9 \\
24 \pm 6 \\
44 \pm 10 \\
104 \%\end{array}$ & $\begin{array}{l}-165 \pm 36 \\
-132 \pm 14 \\
-87 \pm 3\end{array}$ & $\begin{array}{l}15 \pm 35 \\
134 \pm 13 \\
34 \pm 2 \cdot 5\end{array}$ & $\begin{array}{l}180 \\
266 \\
121\end{array}$ & $\begin{array}{l}92 \% \\
49 \% \\
72 \%\end{array}$ \\
\hline $\begin{array}{l}\text { Chloride (mmol/h) } \\
\text { Prevagotomy } \\
\text { Postvagotomy } \\
+ \text { urecholine } \\
\% \text { of prevagotomy }\end{array}$ & $\begin{array}{l}20 \cdot 4 \pm 5 \\
11 \cdot 4 \pm 1 \cdot 8 \\
20 \cdot 4 \pm 3 \cdot 8 \\
100 \%\end{array}$ & $\begin{array}{l}56 \cdot 8 \pm 6 \cdot 6 \\
41 \cdot 6 \pm 1 \cdot 4 \\
52 \cdot 4 \pm 2 \cdot 4 \\
92 \%\end{array}$ & $\begin{array}{l}36 \pm 7 \cdot 4 \\
27 \pm 4 \\
39 \pm 3 \\
107 \%\end{array}$ & $\begin{array}{l}-102 \pm 3 \cdot 2 \\
-111 \pm 13 \\
-80 \pm 16\end{array}$ & $\begin{array}{l}46 \pm 1 \cdot 6 \\
85 \pm 19 \\
16 \pm 6 \cdot 6\end{array}$ & $\begin{array}{r}148 \\
196 \\
96\end{array}$ & $\begin{array}{l}69 \% \\
57 \% \\
83 \%\end{array}$ \\
\hline
\end{tabular}

After vagotomy the pentagastrin was restudied with background infusion of urecholine $20 \mu \mathrm{g} / \mathrm{kg} / \mathrm{h}$.

* Dose of pentagastrin $\mathrm{pmol} / \mathrm{kg} / \mathrm{h}$.

$\dagger$ Mean of individual ratios basal/peak output are given in Col 3. The values for threshold $(\mathrm{T})$ and $\mathrm{Km}$ are derived from the mean dose-response by the exponential model $\mathrm{V}=\mathrm{Vmax}-\mathrm{be} \mathrm{c}^{-\mathrm{cs}} . \mathrm{ED}_{50}=\Sigma(\mathrm{Km}-\mathrm{T})$. The values basal, peak, and basal/peak with urecholine are compared with prevagotomy in line 4 of each set.

kinetic analyses could be made. For example, in the fractional linear transformation described in one of these studies, ${ }^{9}$ only two of three points fell on the line from which $\mathrm{Km}$ and Vmax were reported. Moreover, it is not certain that the supramaximal doses did not cause some reduction in maximal output.

To avoid the deficiencies of prior dose-response studies, we used four doses of pentagastrin which were close enough to each other to calculate Vmax and $\mathrm{Km}$ reliably. Moreover, the exponential model also uses the zero dose point (basal secretion), providing five data points for analysis, and allowed us to divide $\mathrm{ED}_{50}$ into its components, $\mathrm{T}$ and $\mathrm{Km}$. By this analysis we avoided a possibly misleading conclusion that pepsin or chloride secretion are more sensitive to stimuli - for example, $\mathrm{Km}$ in Table 1 - a conclusion which results from the fact that basal:maximal ratios are higher for these two constituents and $\mathrm{Km}$ a smaller proportion of $\mathrm{ED}_{50}$. Thus, though $\mathrm{Km}$ ranged from 15 for pepsin to 76 for acid, in fact $E D_{50}$ was the same for acid, chloride, and pepsin in intact man.

The dose responses provide further insights into other effects of vagotomy on gastric secretion. The reduction in Vmax and the simultaneous increase in $E_{50}$ describes the effect of vagotomy as uncompetitive $^{12}$ rather than competitive, as in the dog where there is no basal secretion. ${ }^{12}$ The decrease in sensitivity of the gastric mucosa to pentagastrin is, in fact, much greater than that reflected by the two to three-fold increase in $\mathrm{ED}_{50}$ (for the new, lower Vmax). If one calculates the amount of exogenous pentagastrin required to stimulate output to $50 \%$ of its prevagotomy maximum, then increases of sixfold (for acid) and 12-fold (for pepsin) reflect the reduced sensitivity of the mucosa. The tetragastrin dose responses of Csendes $e$ al $^{15}$ reflect an almost identical change in acid secretion. These figures tell why vagotomy is such an effective long-term treatment for duodenal ulcer.

Three cholinergic drugs have been used in the type of study reported here. Payne and $\mathrm{Kay}^{6}$ used mecholyl with restoration of histamine-stimulated MAO to $75-100 \%$ of prevagotomy output in five patients. Broome ${ }^{16}$ used carbachol in 10 antrectomised patients, restoring maximum acid output to prevagotomy levels in seven. Roland et al, ${ }^{19}$ also using carbachol in patients with fundic vagotomy, but intact antrum, restored only two of nine patients to prevagotomy pentagastrin maximum acid output. Roland et al later ${ }^{89}$ again found carbachol as well as urecholine $(60 \mu \mathrm{g} / \mathrm{kg} / \mathrm{h})$ to have no effect on maximum acid output stimulated by $15 \mu \mathrm{g}$ pentagastrin $/ \mathrm{kg} / \mathrm{h}$. Urecholine, however, restored pepsin output to levels not different from prevagotomy. ${ }^{8}$ In the present study with urecholine, both acid and pepsin secretion were restored to levels not significantly different from prevagotomy controls.

Thus, of the four studies which reported the use of cholinergic agents after vagotomy, there is only one laboratory ${ }^{3}$ where cholinergic drugs failed to 
improve stimulation of acid secretion. The causes for the discrepancies are not obvious. Carbachol has potent nicotinic as well as ganglionic effects ${ }^{16}$ and is thus probably the wrong choice of cholinergic drug to study muscarinic effects on the stomach. Mecholyl has fewer nicotinic effects but more cardiovascular effects than the other cholinergic agonists and is thus also less suited than urecholine to studies of gastric function. Another difference between the studies of Broome ${ }^{16}$ and of Roland $e t$ $a l^{19}$ is the absence of antrum in the former studies, raising the possibility of an inhibitor released from the antrum (? antral chalone) by carbachol. More studies with bethanechol and appropriate dose responses are needed.

We have sought to define the effects of fundic vagotomy on acid and pepsin secretion both by the pentagastrin dose responses and by cholinergic replacement. The effect of vagotomy on the gastric responses to non-cholinergic stimuli is immediate. Subsequently, in both man and animals, there is a trend to recovery rather than to further loss of responsiveness. In man maximum acid output remains depressed from 30 to $50 \%$, but, up to five or more years later, there is no further deterioration. ${ }^{7}$ There is thus no evidence that vagotomy causes involution or atrophy of the gastric secretory mucosa. Because the effects of vagotomy are immediate and there is restoration in most by cholinergic agents to prevagotomy acid ${ }^{616}$ and pepsin responses $^{8}$ (and this study), we conclude that the effects of vagotomy are functional in man, as they are in the dog, ${ }^{12}$ and presumably result from loss of acetylcholine. Effects similar to those of vagotomy can be produced in man by atropine. ${ }^{14}$

The therapeutic effects of vagotomy thus rest on the marked reduction of basal acid and pepsin secretion and the six- and 12-fold increase in the amount of exogenous pentagastrin, and presumably endogenous secretagogues, which would be required to stimulate the stomach to secrete acid and pepsin respectively at rates of $50 \%$ of preoperative maximum outputs. With such effective brakes on secretion, ulcer recurrence is indeed rare after adequate vagotomy. ${ }^{5}$

This work was supported by NIH Grants AM09260 and MOIRR00032-20. The authors wish to thank Ed Greene, Jacky King, and Philip Goodwin for their techinical assistance, and the Lister Hill Library for their help with the references.
References

1 Hirschowitz BI, Hutchison G. Effects of vagotomy on urecholine-modified histamine dose responses in dogs. Am J Physiol 1975; 228: 1313-8.

2 Hirschowitz BI, Hutchison G. Long-term effects of highly selective vagotomy (HSV) in dogs on acid and pepsin secretion. Am J Dig Dis 1977; 22: 81-95.

3 Roland M, Berstad A, Liavag I. Effect of urecholine and carbacholine on pentagastrin-stimulated gastric secretion after proximal gastric vagotomy in duodenal ulcer patients. Scand J Gastroenterol 1975a; 10: 315-9.

4 Rosato EF, Rosato FE, MacFadyen B. Effect of truncal vagotomy on acid and pepsin responses to histamine in duodenal ulcer subjects. Ann Surg 1971; 173: 63-6.

5 Kronborg O. Review: Completeness of vagotomy: anatomy, pathophysiology and consequences. Scand $J$ Gastroenterol 1981; 16: 577-80.

6 Payne RA, Kay AW. The effect of vagotomy on the maximal acid secretory response to histamine in man. Clin Sci 1972; 22: 373-82.

7 Greenall MJ, Lyndon PJ, Goligher JC, Johnston D. Long-term effect of highly selective vagotomy on basal and maximal output in man. Gastroenterology 1975; 68: 1421-5.

8 Roland M, Berstad A, Liavag I. Decrease in gastric secretion during the first three months after proximal gastric vagotomy in duodenal ulcer patients. Scan J Gastroenterol 1975c; 10: 363-7.

9 Roland M, Berstad A, Liavag I. Effect of carbacholine on pentagastrin-stimulated gastric secretion in healthy subjects. Scand J Gastroenterol 1975b; 10: 357-62.

10 Makhlouf GM, McManus JPA, Card WI. A comparative study of the effects of gastrin, histamine, histalog and mechothane on the secretory capacity of the human stomach in two normal subjects over 20 months. Gut 1965; 6: 525-34.

11 Vatier MM, Cheret AA, Bonfils S. Le dosage automatique de l'activite proteolytique du suc gastrique. Bio Gastroenterol 1968; 1: 15-29.

12 Hirschowitz BI, Hutchinson GH. A working hypothesis for urecholine effects on histamine stimulation of gastric secretion. Scand J Gastroenterol 1973; 8: 569-76.

13 Kronborg O. An evaluation of the insulin test. Copenhagen: Fadls Forlag, 1972.

14 Konturek SJ, Wysocki A, Olesky J. Effect of medical and surgical vagotomy on gastric response to graded doses of pentagastrin and histamine. Gastroenterology 1968; 54: 392-400.

15 Csendes A, Ornsholt J, Venturelli A, Henriquez A. Dose response studies of acid secretion after administration of tetragastrin. Studies in duodenal ulcer patients before and after highly selective vagotomy, hemigastrectomy and truncal vagotomy plus antrectomy. Am J Surg 1980; 139: 832-7.

16 Broome A. Mechanism of the vagotomy-induced suppression of the maximal acid response to histamine in antrectomized duodenal ulcer patients. Scand $J$ Gastroenterol 1967; 2: 275-82. 
17 Goodman AG, Goodman LS, Gilman A, eds. The pharmacological basis of therapeutics, Chapter 5. New York, NY: McMillan, 1980.

18 Hassan MA, Hobsley M. Positioning of subject and of naso-gastric tube during a gastric secretion study. $\mathrm{Br}$ Med J 1970; 1: 458-60.

19 Roland M, Berstad A, Liavag I. Scand J Gastroenterol 1974; 9: 511-8. 